\title{
DEVELOPMENT OF IT SERVICES IN URBAN SPACE - SMART CITY LOGISTICS
}

\section{KONRAD HENRYK BACHANEK}

University of Szczecin, Faculty of Management and Economics of Services, POLAND

e-mail: konrad.bachanek@wzieu.pl

\begin{tabular}{|c|c|}
\hline $\begin{array}{l}\text { RECEIVED } \\
\text { ACCEPTED }\end{array}$ & $\begin{array}{l}10 \text { December } 2018 \\
28 \text { December } 2018\end{array}$ \\
\hline $\begin{array}{l}\text { JEL } \\
\text { CLASSIFICATION }\end{array}$ & 018, Q55 \\
\hline KEYWORDS & urban logistics, IT concepts, urban space management \\
\hline ABSTRACT & $\begin{array}{l}\text { The topic of this article is innovative IT solutions in urban space - analysis of selected concepts. The author } \\
\text { presented practical methods for implementing the concept of management urban space. The development } \\
\text { of urbanized areas is not only innovative the trend of implementing innovative solutions but also for the quality } \\
\text { of life of residents. Exactly that they are today the most important integrator of cities for which innovative IT } \\
\text { concepts are created. }\end{array}$ \\
\hline
\end{tabular}

\section{Introduction}

An essential role in the proper functioning of urbanized urban areas they are currently playing innovative IT solutions. Focused mainly on solving infrastructural problems - closely related to the development of urban space, they improve mobility and eliminate the negative effects of the activity of city users. Undoubtedly, investment is the 
key to improving the prosperity of urban areas for research and development, and better use of existing resources and resources currently available they are often overlooked and wasted.

Striving for development, city authorities implement innovative and often innovative concepts urban space management. Strategic simulations and forecasts for the implementation of selected ideas illustrate the improvement of the quality of life of residents thanks to the improvement of all phenomena taking place in urban space.

The article addressed the topic of innovative IT solutions used in space urban based on selected concepts of urban space management. Author based on the newly the resulting concepts show the effects of implementation in selected cities around the world and make evaluation of the effectiveness of the implemented concept.

\section{A city in motion or the development of urhanized urban areas}

The development of globalization and urbanization processes has made cities become human the basic center of functioning. Shaping urban space in a consistent manner and comprehensive is one of the most important problems of modern urban planning (Lorens, 2014, p. 23). The urbanization process leads to both the development of urban areas and its development, as well and the increase in the number of people living in cities and adopting urban lifestyle.

Analysis of urbanization of cities in highly developed countries over the last decades and the current transformations of Polish urban areas proves that all contemporary urban organisms are subject to cyclical structural changes described by L. Klassena as the phase of the urban life cycle (Jałowiecki, Szczepański, 2002, pp. 65-67).

Urbanization is a socio-cultural process expressed in the development of cities, increase their number, increase their areas and the share of residents in the total number population (Ziobrowski, 2012, p. 27). The development of civilization contributes to the development of processes urbanization, where there is the progression of urban areas. The result is also phenomena related, ie conurbation or suburbanization (Tundys, 2008, pp. 52-56). During the suburbanization process there is a further increase, the fastest in the outer zone. This stage is followed by de-urbanization, where there is a decline in the population from the central parts to the parts external. The last stage of populating cities is reurbanisation. This process takes place modernization and reconstruction of cities - the center. There is also an improvement in quality natural environment together with environmentally friendly innovation. These activities affect increased value added for cities and enable the development of innovative management concepts city.

In Poland, the described phases of urban transformation depend on a number of economic processes to which it is first of all (Węgleński, 2001, pp. 64-69):

a) deindustrialisation - liquidation of inefficient industrial plants;

b) development of high-tech - the latest technologies sector;

c) development of services - especially the so-called production services.

The processes of deindustrialisation have meant that nowadays fewer and fewer cities implement innovative solutions solutions in traditional branches of industry such as energy or mechatronics (Węgleński, 2008). As a result of ongoing transformations, areas of industrial areas urban buildings are a powerful environmental threat for residents.

To be able to fight the negative effects of human activity, the agglomeration's rulers municipalities began to apply the policy of the concept of sustainable development. This concept is strictly connected with the management of an innovative city. The problem stems from causes territorial and social, where urbanization processes are 
cumulative (Słodczyk, Jakubczyk, 2005, p. 19). Sustainable development is one of the great trends at the turn of the 20th and 21st centuries. Concept sustainable development was initiated during the socio-economic-environmental crisis, which in the second half of the twentieth century began to grow rapidly, taking on global sizes. The concept of sustainable development was first used at the conference in Stockholm in 1972.

The mission and goal of a sustainable urban system is its continuous and sustainable development including modern IT solutions that are friendly to the potential passenger public transport. Sustainable development in this area influences the attractiveness of the city for life of residents, their professional activity, attracts tourists or investors and restricts the broadly understood negative impact of the transport function on the quality of the local environment. An efficient communication system also co-creates an open and tolerant city through liquidation barriers to inclusion in the socio-economic life of people with disabilities. This system should also use the advantages resulting from natural conditions, including specific Oder areas position.

In the face of such an extensive meaning of public communication in the development processes of the city, a mission for entities responsible for the area should be creating such a communication system urban, which will be a viable and desirable alternative to individual transport.

The public transport system in accordance with the demands of sustainable development belongs to be perceived in three aspects: environmental, economic and social. The area of sustainable development is the focal point between the social aspect, environmental aspect and economic aspect. Each aspect has its own criteria, which the city must strive to become sustainable. In the environmental aspect, a big role it plays the state of air and water, measured by the level of pollution. It attaches itself here, too much importance to noise or carbon dioxide emissions as a negative side effect using communication means. Based on the social aspect, attention is paid here convenience and satisfaction of transport users as well as security and social cohesion. If it is about the economic aspect, this is the most important element here is the economic capacity of cities to provision of services, production of goods and employment and trade, including resource saving and energy for future generations (W kierunku..., 2013).

The smart development is a practical example of implementing innovative solutions transport in Warsaw. The city purchased an IT system of passenger information at bus stops, which provides necessary information about the bus in time to help the passenger plan their trip and shorten its time (for example, expected time for the bus to arrive) (Wyzwania..., 2015). In addition, routers were deployed VPN designed to work in harsh weather conditions, providing a smooth, safe and fast wireless connectivity in both public transport and also at train stations or in city centers.

The great capabilities of the systems as well as the variety of technologies used are visible in most of the planned investments. It can be seen that some ITS solutions in projects implemented in cities become a standard. This applies especially to dynamic mounting stop information or e-kiosks, enabling quick and unlimited time of day purchasing tickets and charging city cards (itspolska.pl, 2016). The key to the success of the implemented concept is a constant striving for the excellence of urbanized urban areas management is supported by intelligent IT solutions.

Another practical example of an innovative and innovative idea of space management The Smart City concept is urban. The main assumption of Smart City is the integration of technologies with good management (Szczęsnowicz, 2016). The idea of a smart city is aimed primarily at all improving the activities in the eight categories shown in Figure 1. 


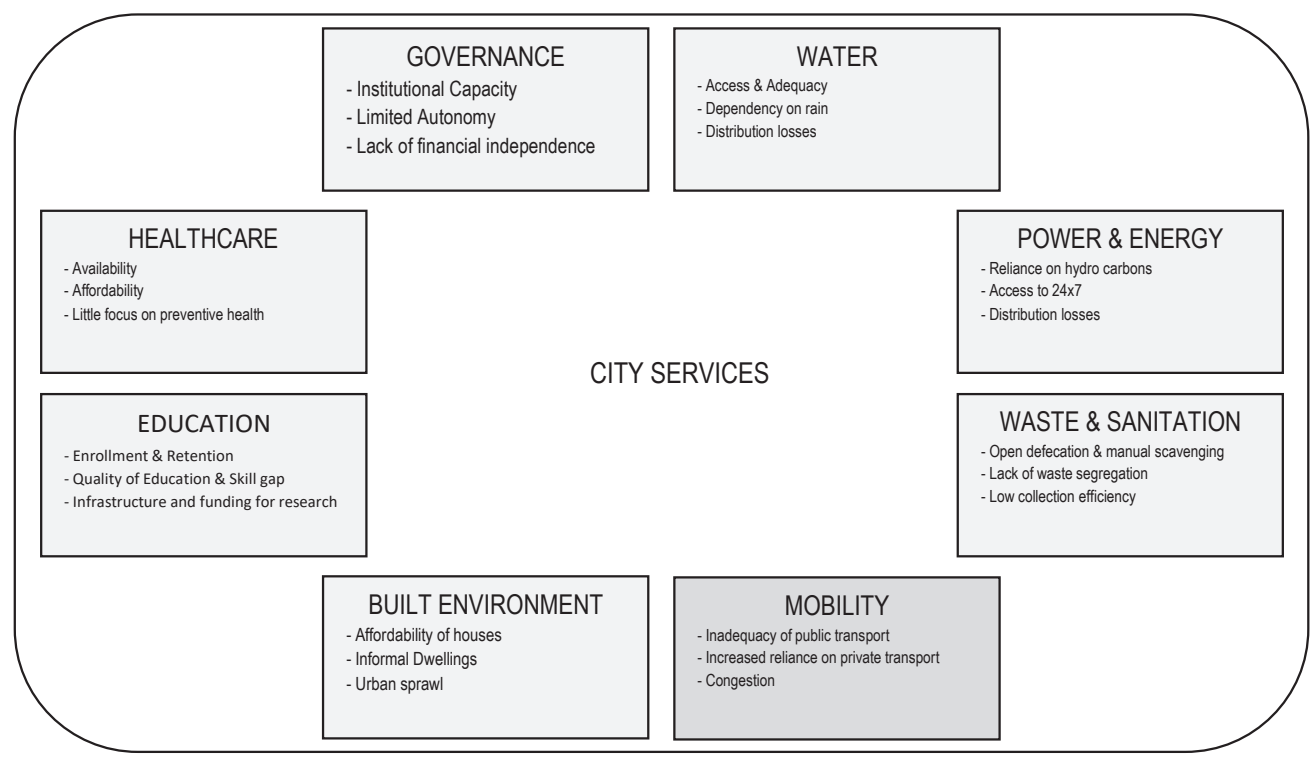

Figure 1. Determinants of the Smart City classification

Source: https://www.kisspng.com (2018).

In composition first category intelligent cities includes citizens. Speech is here both about the residents of cities actively using the goods offered by city as well as passive city users who do not use urban goods such as public transport or city bikes. As a citizen, a person is classified lives in the area of a given urbanized area. The offices include institutions that through their activities, they interact directly and indirectly in the urbanized area. Referring to energy, it takes into account the state of its impact on the natural environment. It aims to eliminate as much as possible its negative impact. Another category is energy-efficient buildings, which as a part of the infrastructure are consistent Smart City urbanized system. Transport is a link in the smart concept, which is a big one problem from the point of view of impact on the natural environment. It strives to be as small as possible using own means of communication (e.g. passenger cars), for transport collective. Infrastructure is the sixth link. A number of road networks are included in it in road, rail, air or inland waterway transport, but also in buildings used for safe and collision-free operation of vehicles.

Under the concept of communication is understood as IT technology that helps to integrate all systems inside the area urbanized. Health is the last link in the Smart City category. In this category are taken under Attention factors affecting the state of well-being of city dwellers.

All eight links strive to improve the quality of life in urbanized areas urban areas. Compliance with the principles of these areas results in increased safety, improvement of the condition natural environment and, above all, satisfaction of city users, which is a key issue determinant determining the proper functioning of the Smart City concept. 


\section{Examples of smart city concept applications}

A practical example of the implementation of Smart concepts is the European initiative "Smart Cities" as part of the social strategy plan in the field of energy technologies (SET-Plan), which supports highly urbanized cities, trying to reduce gas emissions by $40 \%$ greenhouse through sustainable use and energy production by 2020 . This initiative aims to support sustainable energy sources and transport in European areas urban areas. For this purpose, energy-saving buildings, called ZEBs, are created. They are buildings, which have zero carbon dioxide emissions annually.

The European Strategic Energy Technology Plan (SET Plan) provides a European policy tool in the field of energy technologies for Europe. His main the assumption is to strive for the promotion of low-emission technologies by accelerating development knowledge, technology transfer and implementation of ideas up to 2020 (Kylili, Fokaides, 2015). Activity The SET Plan has been launched since 2010. It is still being implemented by European initiatives industrial, which provide the basis for planning and decision-making.

As part of the SET Plan, the following initiatives are distinguished (Dz.U. UE C, 2010):

1. An initiative regarding the use of wind potential.

2. A European initiative to use solar panels.

3. Initiative for electricity networks.

4. Carbon Capture Initiative - using the transport potential.

5. Initiative for the sustainable use of nuclear energy.

6. Industrial bioenergy initiative.

7. Initiative to use the resources of cities and communities.

8. Technological initiative in the field of fuel cells and hydrogen.

Each of the initiatives, described in the Official Journal of the EU of December 22, 2010, supports proecological activities. They are implemented to protect the natural environment, constantly degrading through highly urbanized areas. The Smart City concept takes into account the scope activities of cities, giving them guidelines that must be met. The SET's initiatives are constantly striving to save resources in order to combine energy, transport, information and communication, and technologies in European urban areas. According to forecasts, from 25 to 30 European cities by 2020 will be at the forefront of a low-carbon economy (Kylili, Fokaides, 2015). The goal is to be achieved by adopting a pro-ecological system approach and innovative management, including energy management, performance control, technology low-carbon and intelligent management of supply and demand, focusing their attention on buildings residential local networks power and transport to be able to use them ecologically.

The future of cities with buildings like ZEB is becoming a more and more real initiative highly urbanized areas. New challenges for building automation systems environmentally friendly, which will reduce energy consumption in the building, have become a priority and goal to be implemented in the near future. Innovative initiatives will be able to save both energy and protect our environment from the negative effects resulting from the expansion of urban areas.

The development within Smart City logistics is both innovative management methods urban systems, as well as supporting their technologies. An exemplary model, innovation is supported by cloud computing. It is a model enabling widespread and generally available use of the network. Data from servers are collected into a shared pool configurable computing resources (e.g., networks, servers, storage, applications and services), which are secured, 
and the process of generating them requires minimal management efforts with the website of the service provider (xrgsystems.com, 2015).

Cloud computing is referred to as cloud computing. Smart City is based on effective and pro-ecological prosperity of many companies operating in the city areas the main goal is to make profits with the least possible degradation of the natural environment. This model is mainly oriented at improving work efficiency. Smart City concept it is implemented on many levels of economic life, starting from tactical plans, after strategic plans in areas of urbanized cities (Nowicka, 2008). On every level cloud computing eliminates costs and contributes to limiting unnecessary waste in city logistics. It consists of three distribution models:

1. SaaS (Software as a Service) - is the ability to provide the consumer needed for it functions the appropriate software via the Internet from the selected one provider.

2. PaaS (Platform as a Service) - this is a service that consists in providing the platform IT and appropriate functional tools to facilitate application changes without incurring costs and carrying out works related to their purchase. allows consumers develop their own applications using the tools and services provided by operator. PaaS offers services mainly related to development, testing, dislocation, management and application hosting in the same integrated environment. By eliminating individualism, society can with such the same result, use IT services while caring for the natural environment and contributing to the development of smart cities.

3. laaS (Infrastructure as a Service) - it is a service that enables providing infrastructure computer. The customer is not obliged to purchase servers, licenses for software, space for the data center, network equipment, and current care backups, security and availability of certain functions in your own infrastructure. laaS has a positive effect on both enterprises and consumers. offering comprehensive services of enterprises results in consumer satisfaction. Itself fueling cells affect the country's GDP, thanks to which the state develops and his cities are developing.

Cloud computing aims to generate savings for the budget of the cities that have implemented them and they are constantly using. Thanks to this, consumer spending on IT services increases profitability cities and drive their economy.

\section{Conclusions}

All innovative trends from the right city policy to IT infrastructure increases the mobility, durability and security of smart cities. Socio-social potential economic and infrastructure-technical means that smart cities are growing territorially, creating innovative agglomerations or metropolises. In cities where innovative solutions for urban space management have been implemented there has been an increase in the quality of life of residents and improvement of the natural environment. It strives continue to improve the state of urban areas by using innovative IT tools to be able to leave the environment and a better quality of life to future generations, future residents.

\section{References}

https://www.kisspng.com.

itspolska.pl.

Jałowiecki, B., Szczepański, M. (2002). Miasto i przestrzeń w perspektywie socjologicznej. Warszawa: Wydawnictwo Naukowe Scholar. Kylili, A., Fokaides, P. (2015). The role of zero energy building. Journal Energy Procedia, 15 (7), 86-95. 
Lorens, P. (2014). Współczesne przemiany struktury miast i obszarów metropolitalnych. Warszawa: Politechnika Gdańska.

Nowicka, K. (2008). Smart City Logistics on Cloud Computing. Procedia - Social and Behavioral Sciences, 151, $266-281$.

Słodczyk, J., Jakubczyk, Z. (2005). Małe miasta a rozwój lokalny i regionalny. Katowice: Wydawnictwo Akademii Ekonomicznej w Katowicach.

Szczęsnowicz, A. (2016). Idea Smart City czyli o inteligentnych miastach. Retrieved from: http://dworzynska.com/idea-smartcity-czyli-o-inteligentnych-miastach.

The European Strategic Energy Technology Plan. Dz.U. UE C of 22 December 2010.

Tundys, T. (2008). Logistyka miejska. Warszawa: Difin.

W kierunku zrównoważonego rozwoju miast Europejskich. Kontrast pomiędzy ogólnym efektem politykiUnii Europejskieja osiągnięciami indywidualnymi miast (2013). Retrieved from: www.uaue.zarz.agh.edu.pl/Panel_tematyczny/P_Laconte_ISOCARP.pdf.

Węgleński, J. (2001). Miasta Ameryki u progu XXI wieku. Warszawa: Wydawnictwo Naukowe Scholar.

Wyzwania inteligentnego transportu (2015). Retrieved from: http://dominteligentny.pl/2015/wyzwania-inteligentnego-transportu. xrgsystems.com.

Ziobrowski, Z. (2012). Urbanistyczne wymiary miast. Kraków: Instytut Rozwoju Miast.

Cite this article aS: Bachanek, K.H. (2018). Development of IT services in urban space - Smart City Logistics. European Journal of Service Management, 4 (28/2), 27-33. DOI: 10.18276/ejsm.2018.28/2-03. 